\title{
Fusarium mycotoxins as a problem in finnish feeds and cereals
}

\author{
EEVA KARPPANEN, ALDO RIZZO, SEIJA BERG, ERJA LINDFORS and \\ RIITTA AHO \\ National Veterinary Institute, P. Box 368, \\ 00101 HELSINKI, Finland
}

\begin{abstract}
In the past mycotoxins have been only an occasional minor problem for domestic animals in Finland. In 1982 a large number of intoxicated animals were suspected of being affected by mycotoxicosis. Later on imported maize was found to be the cause of the illness. After 2 years of investigations we concentrated our attention on Fusarium toxins, and in the autumn of 1984 we were able to detect the presence of trichothecenes in feeds. The rainy summer of 1984 created very favourable conditions for the growth of moulds. The production lines of some feed factories were contaminated by Fusarium fungi. The number of intoxicated animals increased drastically. Two strains of Fusaria were isolated at a feed factory. Since the trichothecenes have strong dermotoxic and cytotoxic effects, biological tests were used in this investigation. Capillary gas chromatography and mass spectrometry were used to identify and quantify the trichothecenes.

Qualitative and quantitative results are presented together with the symptoms observed in the intoxicated animals.

The reliability and the significance of the results have been discussed. Despite what has earlier been believed, it is evident from our results that trichothecenes are unstable in cereals and feeds. In fact, samples which originally proved to be toxic were found to be almost toxinfree after 3 to 6 months storage at $+4^{\circ} \mathrm{C}$.
\end{abstract}

\section{Introduction}

Fusarium fungi are common contaminants of Finnish crop plants (YLIMÄKI 1970, UOTI and YLIMÄKI 1974), and it has long been known that they cause diseases in domestic animals when they grow as parasites on wild and cultivated plants or other feedstuffs (RAINIO 1932), (KoRPINEN et al. 1972), (RoINE et al. 1971). However, the Fusarium toxins have not been a serious trouble in Finland in the past. The most important Finnish report on this subject deals only with zearalenone. Contamination by Fusarium fungi was exceptionally heavy in 1972, although it did not create serious problems to animals (KUKKULA et al. 1975). An extensive study carried out in 1976 and 1977 on crops collected in different parts of Finland (YLIMÃKI et al. 1979) showed that 24 of the 230 samples analyzed contained zearalenone, and 4 samples T- 2 toxin at concentrations ranging from 0.1 to $40.0 \mathrm{mg} / \mathrm{kg}$ 
and 10 to $50 \mathrm{ug} / \mathrm{kg}$ respectively. Suspected mycotoxicosis was very unusual in Finland up until 1982, when a large number of cases of intoxication in mink, farm-foxes, calves and pigs were reported. The symptoms pointed to mycotoxicosis. In the autumn of 1982 our laboratory was contacted by some of the feed producers who asked us to carry out an investigation on this subject since the materials used to produce feed for several different animal species were suspected as the cause of the illness. The raw-material in question was imported maize. Samples of the maize and the commercial feeds were analyzed for possible poisonous compounds, with negative results. The results of the analyses for zearalenone and several other mycotoxins were negative, too. Part of the imported maize was used up and part destroyed, but new cases of suspected mycotoxicosis broke out in 1983 and 1984. In autumn 1984 Fusarium toxins, trichothecenes, which are very toxic for animals and humans were detected in the feeds. The summer and autumn of the same year were rainy and wet in Finland and favourable conditions were created for the growth of moulds. The number of intoxicated animals drastically increased. In all of the cases we considered the animals had received commercial feed. Inspections carried out at the feed factories showed that the production lines were contaminated. Water had condensed in some places and colonies of Fusarium fungi, which were isolated and identified as $F$. graminearum and $F$. poae were found growing there.

\section{Mycological investigation}

3700 colonies of Fusarium poae (Peck) Wollenweber and 1700 colonies of Fusarium graminearum Schwabe were isolated per $\mathrm{g}$ feed on potato dextrose agar (Difco 0013-01-4) after incubation for one week in the light at $+25^{\circ} \mathrm{C}$. The taxonomy of Booth (Воотн 1971) was used in identification.

Fusarium graminearum rapidly filled the petri dish, producing floccose brownish rose- coloured aerial hyphae. The reverse side of the colony turned vinaceous red. Few macroconidia were seen on the aerial hyphae. The size of the sickle-shaped conidia was $4-5 \times$ $30-50$ um and they had well marked foot cells. Septation varied from 3 to 5 . Chlamydospores were not found.

$F$. poae grew as a powdery, reddish colony, which had a red reverse side. Great numbers of globose to ampulliform microconidia were seen on the lateral phialides. Their size was $5 \times 8$ and $5 \times 5$ um. Macroconidia were not detected, but a few chlamydospores were found in the cultures. The colonies were dry owing to the lack of slime production.

\section{Materials and methods}

167 samples have been analyzed in our laboratory. About 75 per cent of these were commercial feed and the rest consisted of different species of cereal. We were interested in detecting the six trichothecenes which, as reported by Ueno (UENO 1983) are natural contaminants in cereals. The only difference was that we used the HT-2 toxin in our mixture of standards instead of acetyldeoxynivalenol. The structure of the six trichothecenes, which are sesquiterpenoids with a tricyclic skeleton containing an epoxide ring, a double bond in position 9-10 and which are characterized as 12,13-epoxytrichotecenes, are shown in Fig. 1. Ueno divided these compounds into two groups according, among others, to their chemical characteristics: type A (T-2 toxin, HT-2 toxin and diacetoxyscirpenol) and type B (deoxynivalenol, nivalenol and fusarenon-X).

Since the trichothecenes are both strongly cytotoxic and dermotoxic, it is convenient to screen all of the samples by biological test in order to detect for the presence of contaminated materials.

Cell culture, rabbit skin and brine shrimp (Artemia salina) tests (KORPINEN 1974) were used in the investigation. Those samples which gave negative results in the biological test were not analyzed by chemical methods. A large 
number of domestic animals suspected of having died as a result of mycotoxicosis have been investigated in the department of histopatology, microbiology and virology at our institute in order to exclude any other possible causes of death. Meat and liver extracts of the carcasses were analyzed for the presence of toxic compounds using the cell culture test.

\subsection{Biological tests}

\section{Cell culture $R K-13$}

(Rabbit kidney cell line 13)

a) $10 \mathrm{~g}$ of meat or liver homogenate were extracted with $50 \mathrm{ml}$ of chloroform. The solvent was evaporated on a Rotavapor and the residue transferred to a test tube with diethylether. After evaporation of the solvent the residue was suspended in $0.8 \mathrm{ml}$ of nut oil and $1.2 \mathrm{ml}$ of a $1 \%$ aqueous solution of Tween 20. The suspension was mixed for 20 seconds on a cyclomixer and then $70 \mathrm{ul}$ of the sample were added to $1 \mathrm{ml}$ of the cell culture at the time of seeding. Eegle's minimum essential Medium (MEM) supplemented with $10 \%$ foetal calf serum, penicillin and streptomycin, was used throughout the work.

b) $1 \mathrm{~g}$ of meat or liver homogenate was extracted with $10 \mathrm{ml}$ of water, filtered through filter paper and $70 \mathrm{ul}$ of the sample were analyzed as in point a). The cell cultures were inspected after 24 and 48 hours.

Preparation of the feed sample for biological tests and chemical analysis

The procedure used in extracting and purifying the sample is a modification of the method described by Dohi et al. (DoH 1984).

\section{Extraction}

$20 \mathrm{~g}$ of feed or cereal were milled to a fine homogeneous powder and extracted 2 times with $150 \mathrm{ml}$ of methanol-water $(95: 5)$ on a flask shaker for 1 hour. The extract was fil- tered through filter paper, concentrated to a small volume on a Rotavapor, transferred to a test tube by washing 3 times with $3 \mathrm{ml}$ of toluene-acetone ( $4: 2)$ and evaporated to dryness. The residue was redissolved in $2 \mathrm{ml}$ of toluene-acetone $(4: 2)$ and purified on a chromatographic column containing $7 \mathrm{~g}$ of silica gel, with $4 \mathrm{~g}$ of anhydrous sodium sulfate on the top and $2 \mathrm{~g}$ on the bottom. Hexane was used to pack the column which had been washed with $60 \mathrm{ml}$ of toluene and eluted with $100 \mathrm{ml}$ of acetone. The eluates were evaporated on a Rotavapor and redissolved in $500 \mathrm{ul}$ of acetone (solution " $\mathrm{A}$ ").

\section{Rabbit skin test}

Young Albino rabbits were shaved on the dorsal region one day before the test. The skin was accepted for use in the test if there were no signs of wounds or irritation. 25 ul of solution " $\mathrm{A}$ " were seeded on the skin in the dorsal region in as small a spot as possible. The rabbit's dorsum was inspected every day for one week, and compared with a control area on the same animal.

\section{Artemia salina (Brine shrimps)}

225 ul of solution "A»" were evaporated using a nitrogen stream in a test tube. $2.5 \mathrm{ml}$ of an aqueous solution of sea-salt were added to the tube and also to a control tube. The shrimp's eggs had been grown in a special hatcher in $6 \%$ saline water for 48 hours. The larvae separate themselves from the eggs because they are phototrophic. A spoonful (about 30 larvae) was transferred to each tube and inspected after 17 and 24 hours to determine the number and condition of the surviving larvae.

\subsection{Chemical analysis}

\section{Purification}

$250 \mathrm{ul}$ of solution "A»" were evaporated, the residue was dissolved in $35 \mathrm{ml}$ of methanol- 


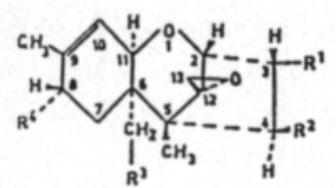

Type A

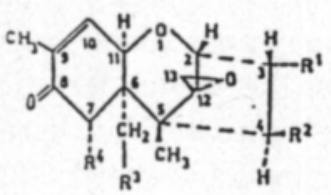

Deoxynivalenol

Fusarenon - $X$

Niválenol

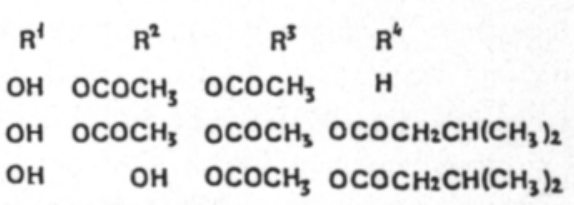

$\begin{array}{lrll}\mathrm{OH} & \mathrm{H} & \mathrm{OH} & \mathrm{OH} \\ \mathrm{OH} & \mathrm{OCOCH}_{3} & \mathrm{OH} & \mathrm{OH} \\ \mathrm{OH} & \mathrm{OH} & \mathrm{OH} & \mathrm{OH}\end{array}$

Type $B$

Fig. 1. Structure of six Mycotoxins produced by Fusarium species.

water (5:30) and extracted two times with 30 $\mathrm{ml}$ of hexane. The upper phase was discarded and the lower phase evaporated to dryness and redissolved in $10 \mathrm{ml}$ of chloroform-methanol $(9: 1)$ (solution $» \mathrm{~B} »)$.

A chromatographic column was prepared as follows: Florisil was treated with hot methanol for about 1 hour, filtered through a sintered glass and activated overnight in an oven at $105^{\circ} \mathrm{C} .2 \mathrm{~g}$ of anhydrous sodium sulfate (at the bottom), $10 \mathrm{~g}$ of Florisil and $5 \mathrm{~g}$ of sodium sulfate (at the top) were packed with chloroform and the column was washed with $30 \mathrm{ml}$ of chloroform-methanol $(9: 1)$.

Solution "B» was transferred to the Florisil column. The trichothecenes were eluted with $150 \mathrm{ml}$ of chloroform-methanol $(9: 1)$ and the solvent was evaporated off.

The residue was transferred to a Sep-Pack $\mathrm{C}_{18}$ cartridge using $150 \mathrm{ul}$ of methanol $40 \%$. The trichothecenes were eluted with $40 \mathrm{ml}$ of the same solution and the solvent evaporated to dryness. This purification is usually sufficient for cereals, grains and some of the feeds, but additional purification is needed in the case of fish feed, for example. A plug of glasswool, $0.7 \mathrm{~g}$ of neutral alumina and $0.3 \mathrm{~g}$ of activated charcoal were placed inside a Pasteur pipette. The residue was dissolved up in $2 \mathrm{ml}$ of acetonitrile-water $(84: 16)$, transferred to the column, eluted with $20 \mathrm{ml}$ of the same solution and evaporated to dryness.

\section{ECD-Gas chromatography}

The residue of the eluates was silylated with $100 \mathrm{ul}$ of trimethylsilylimidazole in a $2 \mathrm{ml}$ glass stoppered tube for 1 hour at $100^{\circ} \mathrm{C}$. After the reaction the sample was diluted with $1 \mathrm{ml}$ of hexane and washed with $1 \mathrm{ml}$ of water. $1 \mathrm{ul}$ of the upper phase was injected in the splitless mode. The gas chromatograph was a Varian 3700 equipped with a fused silica column ( 25 meters, inner diameter $0.3 \mathrm{~mm}$ ), bonded phase $\mathrm{OV}-1,{ }^{63} \mathrm{Ni}$ electron capture detector operated at $290^{\circ} \mathrm{C}$, injector temperature $260^{\circ} \mathrm{C}$. The carrier gas was helium at a flow rate of $2 \mathrm{ml} / \mathrm{min}$, the make up gas nitrogen at a flow rate of $30 \mathrm{ml} / \mathrm{min}$. The sample was injected at $40^{\circ} \mathrm{C}$; after 1 minute the temperature was programmed to $160^{\circ} \mathrm{C}$ at $45^{\circ} \mathrm{C} / \mathrm{min}$ and then to $250^{\circ} \mathrm{C}$ at $2^{\circ} \mathrm{C} / \mathrm{min}$. The amount of trichothecenes was obtained using an integrator (Varian model 4270) by comparing with standard solutions. The samples were injected at intervals of $2-3$ hours during the same day in order to correct the variations in detector response. The recovery and detection limits of the trichothecenes were calculated from spiked samples, and their coefficient of variation from five replications of the same analysis. The detection limits for the trichothecenes analyzed by GC-ECD, their recovery and coefficient of variation are reported in Table 1. The derivatized trichothecenes remain stable when kept in a freezer, otherwise it is 
advisable to analyze them on the same day that the derivatives have been prepared.

\section{GC-Mass spectrometry}

The sample was first analyzed by ECD-gas chromatography. In cases peaks were detected with the same retention time as some of the trichothecenes, the sample was concentrated to a volume of $100-50 \mathrm{ul}$ and analyzed again by GC-MS.

The gas chromatograph was a DANI 3800 HR equipped with a 17-meter-long fused silica column and bonded phase OV-1. The mass spectrometer was a JEOL DX-300 equipped with a data system (JMA-2000). The instrument was used in the electron impact mode. The ion source temperature was $200^{\circ} \mathrm{C}$, electron energy $70 \mathrm{eV}$, ionization current 200 $\mathrm{uA}$, resolution 1000 , and interface temperature $250^{\circ} \mathrm{C}$. If the concentration of the trichothecenes was high enough the sample was analyzed in the low resolution mode. The components were located on the basis of the mass chromatograms and their spectra used for the identification of the mycotoxins. This was done by comparing the spectra with reference data and with trimethylsilyl derivatives of standard compounds. In most of the cases the instrument was operated in the selecting ion monitoring mode. Two ions were monitored for each mycotoxin (see Table 2) and the results were compared with those obtained by GC-ECD in order to confirm the presence of the trichothecenes in the sample.

In the case of uncertain results the identity was confirmed by monitoring the eight most prominent ions in the spectrum of the trichothecene in question.

\section{Results and discussion}

The cytotoxicity of the six trichothecenes analyzed in the study are shown in Table 3.

The trichothecenes of type B (DON, NV and $\mathrm{F}-\mathrm{X})$ are much less cytotoxic than those of type A (T-2, HT-2, DAS). The concentra- tion of the trichothecenes has to be at least $100 \mathrm{ug} / \mathrm{kg}$ and $0.5 \mathrm{ug} / \mathrm{kg}$ for DON and T-2 respectively, for the sample results to by cytotoxic.

This method is very suitable for testing certain types of food samples when very low concentration of trichothecenes or some of their metabolites have to be detected.

Table 1. Quantitative determination of trichothecenes in feeds by GLC-ECD.

\begin{tabular}{lccc}
\hline Trichothecene & $\begin{array}{c}\text { Detection } \\
\text { limit ug/kg }\end{array}$ & $\begin{array}{c}\text { Recovery } \\
\%\end{array}$ & $\begin{array}{c}\text { Precision } \\
\text { CV \% }\end{array}$ \\
\hline $\begin{array}{l}\text { Diacetoxyscirpenol } \\
\text { (DAS) }\end{array}$ & 7 & 90 & 5 \\
T-2 toxin (T-2) & 20 & 90 & 15 \\
HT-2 toxin (HT-2) & 10 & 90 & 12 \\
Deoxynivalenol & & & \\
(DON) & 1 & 80 & 5 \\
Fusarenon-X & & & \\
(F-X) & 1 & 80 & 7 \\
Nivalenol (NV) & 1 & 80 & 8 \\
\hline
\end{tabular}

Table 2. Ions monitored for the detection of trichothecenes.

\begin{tabular}{lc}
\hline Trichothecene & $\mathrm{m} / \mathrm{z}$ \\
\hline Deoxynivalenol (DON) & $422-512$ \\
Fusarenon-X (F-X) & $480-570$ \\
Nivalenol (NV) & $482-585$ \\
Diacetoxyscirpenol (DAS) & $378-379$ \\
T-2 toxin (T-2) & $436-437$ \\
HT-2 toxin (HT-2) & $466-467$ \\
\hline
\end{tabular}

Table 3. Cytotoxicity of the trichothecenes to cultured cells.

\begin{tabular}{lcr}
\hline Trichothecene & $\begin{array}{c}\text { Concentration } \\
\text { ng/ml }\end{array}$ & Results \\
\hline DON & 35.0 & ++ \\
& 3.5 & - \\
NV & 17.50 & + \\
& 1.75 & - \\
F-X & 17.50 & +++ \\
& 1.75 & + \\
DAS & 1.75 & +++ \\
& 0.175 & + \\
T-2 & 1.75 & ++ \\
& 0.175 & + \\
& 0.0175 & +++ \\
HT-2 & 17.50 & +++ \\
& 1.75 & + \\
& 0.0175 & + \\
\hline
\end{tabular}

$1-=$ not cytotoxic; $+=$ slightly cytotoxic; $++=$ $50 \%$ of cells dead, $+++=100 \%$ of the cells dead. 
Rainbow trouts were the kind of animals which had the largest losses because of the very many ill and dead fishes. Several hundred fishes had died in about 20 fish-farms and, in addition, a very large number had been severely injured. The cell toxicity test gave positive results mainly for the water extract of their flesh and the chloroform extract of their livers. However, when this test gives a positive result for a liver extract it does not definitely mean that trichothecenes are present. The liver from fish cought in the sea sometimes also gave positive results.

\section{Rabbit skin test}

The effects and concentrations of the six trichothecenes applied to the rabbit skin are reported in Table 4. Although being very sensitive, the evaluation of toxicity using this method is not as accurate as the cell culture test and the results are not always reliable. Furthermore, the skin may suffer from a bacterial infection some days after the start of the test, thus making the inflammed area appear worse than it really is. However, the results show that DON and NV have a weaker dermotoxic effect than toxins of the T-2 type. The exception to this is F-X which appeas to be very dermotoxic. Four different mixtures of randomly selected trichothecenes were tested. When the effect of mixture 1 is compared over a period of seven days with that of DON, NV or DAS alone, it is evident that the effect is much stronger when more than one toxin is present. This may be true not only as regards the dermotoxic effect, but also as general intoxication when contaminated feed is consumed. Our samples frequently contained more than one trichothecene.

The smallest amounts of T-2 and HT-2 toxins detectable by the rabbit skin test are $0.025 \mathrm{ug}$ and $0.250 \mathrm{ug}$ respectively (YLIMÄKI et al. 1979).

\section{Brine shrimp test}

The results of our experiments show that the brine shrimp test is not suitable for test-

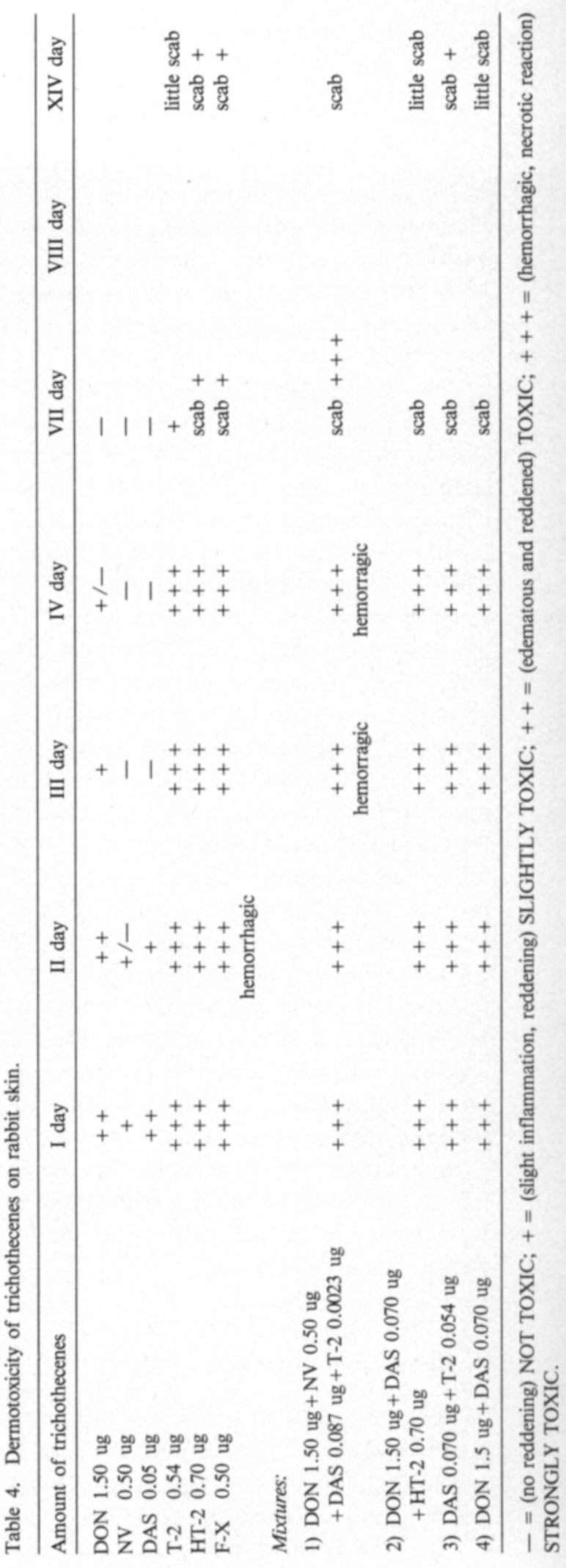




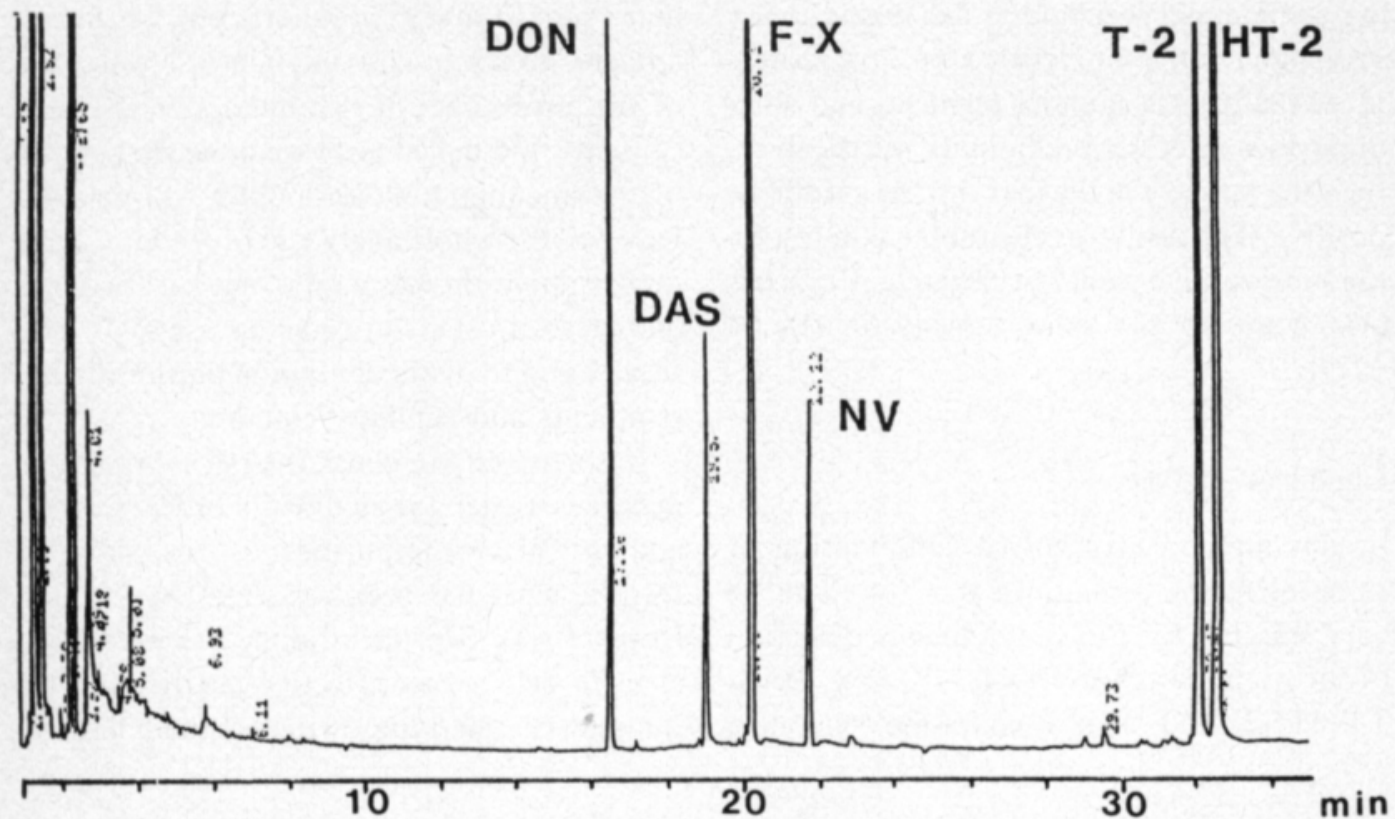

Fig. 2. Gas chromatographic separation of silylated standard mycotoxins on a 25 meter fused silica column. Bonded phase OV-1. Detector ECD. (See text).

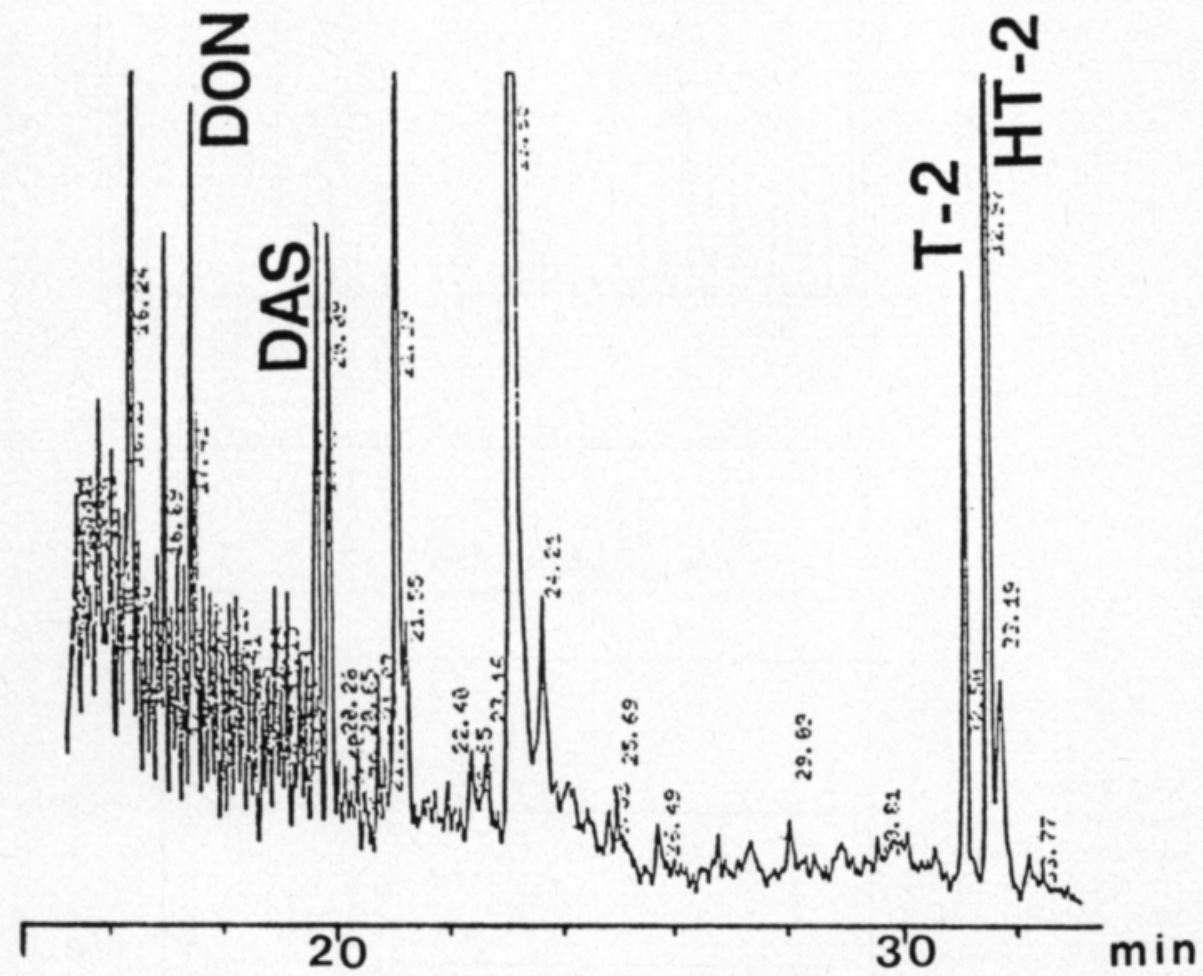

Fig. 3. ECD gas chromatogram of an extract of naturally contaminated fish feed. 
ing commercial feed and grains owing to the very high number of incorrect positive results. If the sample still contains pigments and other impurities after the preliminary purification, then the larvae will die and the test results be positive. The result for the rabbit skin test on the same sample would be negative. Prior has also come to the same conclusion (PrIOR 1979).

\section{Chemical analysis}

This method involving a combination of three different techniques was found to be very suitable for the simultaneous detection of the trichothecenes (DON, NV, F-X, DAS, T-2, HT-2), and can be used for the qualitative and quantitative determination of small amounts of mycotoxins in grain and feed. One of the advantages of this method is that because the biological tests are done first, none of the uncontaminated samples will be subjected to the whole analytical procedure. Particular attention was paid to the purification and clean-up steps in order to use high sensitivity and to avoid contamination of the instruments and capillary columns.

It is necessary to check the purity of all the materials used in the analyses in order to avoid adding further impurities to the sample. Despite what has been reported (ROSEN and RoSEN 1984), Sep-packs alone are not sufficient to achieve an effective purification of samples of this type owing to their limited

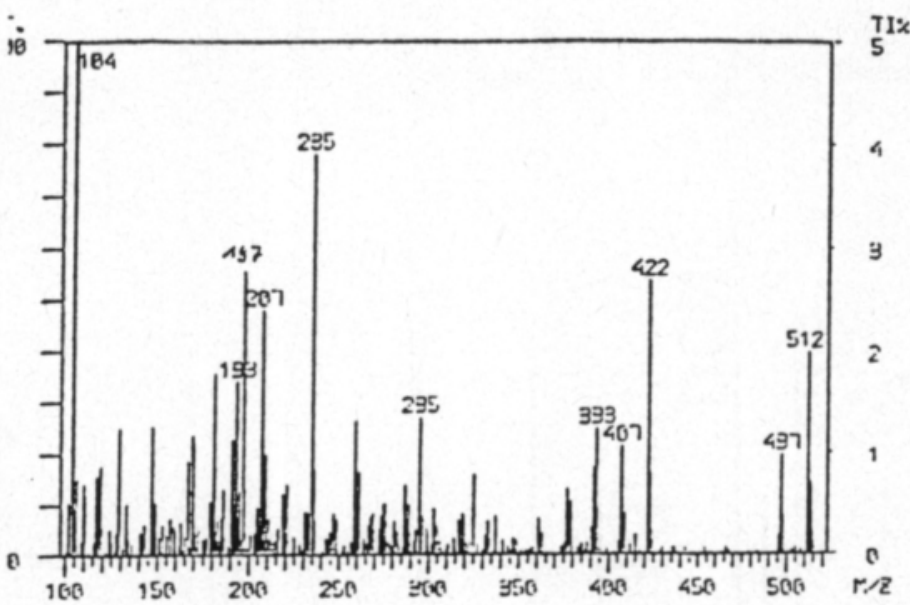

Fig. 4. Mass chromatogram analysis (A) of a silylated extract of maize. The electron impact mass spectrum (B) confirms the presence of DON in the sample.

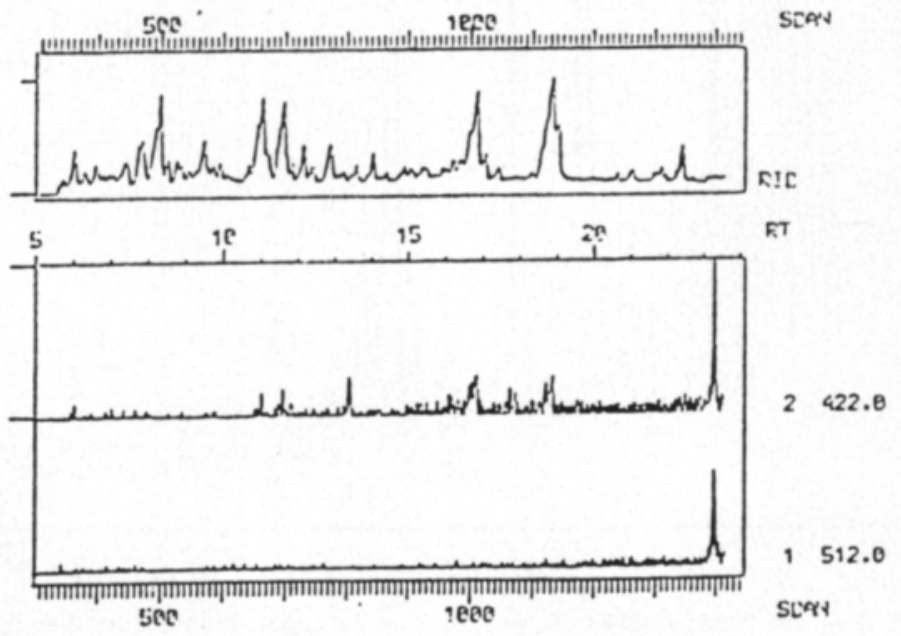


capacity. Trichothecenes of the type "A» and "B» are often present in the same feed. They can be detected if sufficient material is analyzed and if the sensitivity of the method is high enough.

The toxins of type B, when analyzed by $\mathrm{ECD}$, give a response which is about 40 times higher than that for type A. This is due to the presence of a conjugated carbonyl group in position 8 on their molecule. It should be pointed out here that the detection limit, as well as the good repeatability of the results, are affected by the amount of impurities in the sample. Large amounts of impurities will interfere in the derivatization step and possibly act as a negative catalyst in the injection chamber, thus decreasing the detectability of trichothecenes.

The results of our analyses on some of the feed samples and the symptoms observed in the animals which had consumed the feed are reported as an example in Table 5.

The case of the horses fed with domestic oats reported in Table 5 is the only case of animals fed with crops harvested in Finland that we know for certain were contaminated by trichothecenes.

Table 5. Amount of trichothecenes detected in the feeds and some of the symptoms observed in the animals.

\begin{tabular}{|c|c|c|c|}
\hline Kind of feed & Toxin & $\begin{array}{l}\text { Amount } \\
\text { in ug } / \mathrm{kg}\end{array}$ & Symptoms \\
\hline Fish feed 1. & $\begin{array}{l}\text { DON } \\
\text { T-2 } \\
\text { HT-2 }\end{array}$ & $\begin{array}{r}60 \\
705 \\
10\end{array}$ & \\
\hline Fish feed 2. & $\begin{array}{l}\text { DON } \\
\text { T-2 } \\
\text { HT-2 }\end{array}$ & $\begin{array}{r}38 \\
206 \\
90\end{array}$ & Ill or dead rainbow trout. \\
\hline Fish feed 3. & $\begin{array}{l}\text { DON } \\
\text { DAS } \\
\text { T-2 }\end{array}$ & $\begin{array}{r}1 \\
41 \\
409\end{array}$ & \\
\hline Mink feed 1. & $\begin{array}{l}\text { DON } \\
\text { DAS } \\
\text { T-2 }\end{array}$ & $\begin{array}{r}32 \\
230 \\
109\end{array}$ & $\begin{array}{l}\text { 1) Minks died suddenly. } \\
\text { No visible injuries. }\end{array}$ \\
\hline Mink feed 2 . & $\begin{array}{l}\text { DON } \\
\text { DAS } \\
\text { T-2 }\end{array}$ & $\begin{array}{r}47 \\
155 \\
23\end{array}$ & $\begin{array}{l}\text { 2) Hemorrhage in the stomach } \\
\text { cavity. }\end{array}$ \\
\hline Swine feed 1. & $\begin{array}{l}\text { DON } \\
\text { DAS } \\
\text { T-2 } \\
\text { HT-2 }\end{array}$ & $\begin{array}{r}120 \\
60 \\
490 \\
207\end{array}$ & $\begin{array}{l}\text { Refuse to eat, loss in weight, } \\
\text { gastric ulcer, abortion. }\end{array}$ \\
\hline Dog feed 1. & $\begin{array}{l}\text { DON } \\
\text { DAS }\end{array}$ & $\begin{array}{r}15 \\
6\end{array}$ & $\begin{array}{l}\text { Two dogs died; lungs edemic } \\
\text { and brain hemorrhage. }\end{array}$ \\
\hline Dog feed 2. & $\begin{array}{l}\text { DON } \\
\text { T-2 } \\
\text { HT-2 }\end{array}$ & $\begin{array}{l}14 \\
37 \\
12\end{array}$ & \\
\hline Reindeer feed & $\begin{array}{l}\text { DON } \\
\text { DAS } \\
\text { HT-2 } \\
\text { NV }\end{array}$ & $\begin{array}{r}52 \\
766 \\
23 \\
10\end{array}$ & $\begin{array}{l}\text { Reindeers had a stomach illness, } \\
\text { collapsed and died. }\end{array}$ \\
\hline Domestic oats 1 & $\begin{array}{l}\text { DON } \\
\mathrm{T}-2\end{array}$ & $\begin{array}{r}8 \\
50\end{array}$ & $\begin{array}{l}4 \text { horses died; a lot of intestinal } \\
\text { gas. } 2 \text { of them had intestinal } \\
\text { hemorrhage. }\end{array}$ \\
\hline Domestic oats 2 & DON & 6 & \\
\hline
\end{tabular}


It is difficult to obtain representative samples of cereals and feeds because the mycotoxins are not distributed homogeneously and very large amounts of material have to be mixed together before a sample can be taken. Our results concerning the toxicity of the trichothecens cannot be compared with those reported in the literature for the toxicity of individual mycotoxins (Mirocha 1983) because our samples contained more than one. The feedstuffs were analyzed between 3 to 6 months after they had caused intoxication in animals. The samples had been stored at $+4 \mathrm{C}$ in plastic containers. We believe that the results shown in Table 5 represent the amount of trichothecenes at the time the analyses were carried out, and not the amount when the animals were given the feed. We have analyzed a second time some of the feeds which proved to be very toxic six months earlier by biological methods. The results of the test on the second occasion were negative and the chemical analysis showed only trace amounts of DON.

The T-2 and HT-2 toxins were still present in the samples in February, but no longer in April of the same year. DAS, on the other hand, was still detected in some of the feedstuffs. Most of the samples still contained trace amounts of DON in April. These observations indicate that trichothecenes are degraded in the samples over time. The trichothecene problem has occurred in three consecutive years in Finland. Each year, however, the problem disappears by spring and no further complaints reported. One possible reason for this could be the lability of trichothecenes during storage. Scott et al. report that the level of DON in wheat decreases. The concentration of DON in their samples decreased in July 1983 from 1.56 to $0.21 \mathrm{ug} / \mathrm{g}$ over a period of one week, and from 0.21 to $0.11 \mathrm{ug} / \mathrm{g}$ in four days. The wheat was stored for one month in air-tight bags at $+5 \mathrm{C}$ prior to analysis. The possible explanations reported by Scott et al. are: reaction with plant components, metabolism by host plant enzymes, degradation of
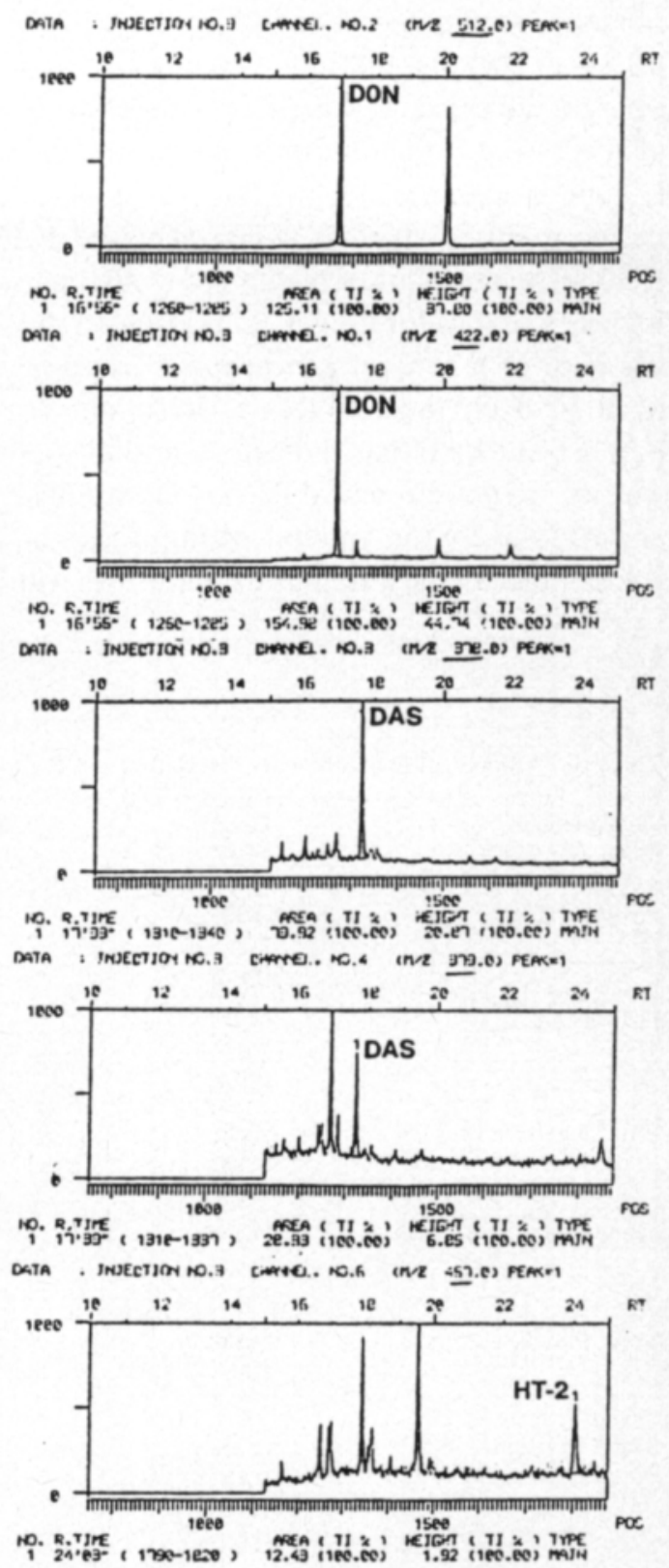

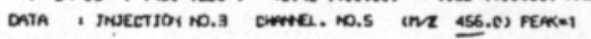

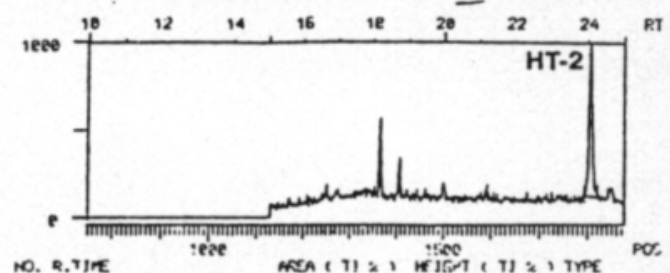

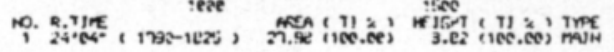

Fig. 5. GC/MS selected ion monitoring analysis of a derivatized extract of naturally contaminated fish feed. 
DON by microorganisms (ScotT et al. 1984). We have also noticed a decrease in trichothecenes, but in our case the degradation occurred during a longer period of storage and it would appear that DON has not degraded as quickly as in the case of Scott. In our case DON persisted for a longer time than the other mycotoxins. At the moment, however, we know too little about the stability of trichothecenes in the samples and further investigations are needed to clarify this question.

Acknowledgements. We are grateful to department of virology at our institute for assisting in the cell culture tests.

\section{References}

Bоотн, C. 1971. The genus Fusarium. Commonwealth Mycological Institute, Kew, Surrey, England.

Dohi, Y., Watanugi, F., Kital, H., Kosaka, K., Ichinoe, М. \& Онва, К. 1984. Determination of trichothecene mycotoxins in barley by FID-GC after clean up on anion-exchange Sephadex. J. Food Hyg. Soc. Japan. 25: 1-9.

Korpinen, E-L., Kallela, K. \& Ylimăkı, A. 1972. Estrogenic activity of Fusarium graminearum on rats in experimental conditions. Nord. Vet. Med. 24: $62-66$.

KORPINEN, E-L. 1974. Studies on Stachybotrys alternans. Acta Path. Microb. Scand. Sect. B. 82: 465-469.

KukKula, M., Berger, R. \& HintikKa, E-L. 1975. Tulokset Maa- ja metsătalousministeriön eläinlaaăkintőosaston suorittamasta punahometiedustelusta v. 1972 - 73 . Suomen Eläinlăăkärilehti 81: 559-566.

Mirocha, C.J. 1983. Development in food science. Trichothecenes. 4: 177-193. Ed. Ueno, Y., Kodansha/ Elsevier, New York.

Prior, M.G. 1979. Evaluation of brine shrimp (Artemia salina) larvae as a bioassay for mycotoxins in animal feedstuffs. Can. J. Comp. Med. 43: 352-355.

Rainıo, A.J. 1932. Punahome Fusarium roseum Link. Gibberella saubinetti Sacc. ja sen aiheuttamat myrkytykset kaurassa. Valt. Maatal. Koetoim. Julk. 50: $1-45$.

Roine, K., Korpinen, E-L. \& Kallela, K. 1971. Mycotoxicosis as a probable cause of infertility in dairy cows. Nord. Vet. Med. 23: 628-633.

Rosen, R.T. \& Rosen, J.D. 1984. Quantification and confirmation of four Fusarium mycotoxins in corn by gas chromatography-mass spectrometry-selected ion monitoring. J. Chromat. 283: 223-230.

Scott, P.M., Nelson, K., Kanhere, S.R., Karpinski, K.F., Hayward, S., Neish, G.A. \& Teich, A.H. 1984. Decline in Deoxynivalenol (Vomitoxin) concentrations in 1983 Ontario winter wheat before harvest. Appl. Environm. Microbiol. 48: 884-886.

UENO, Y. 1983. Developments in food science. Trichothecenes. 4: 4-10. Ed. Ueno, Y., Kodansha/Elsevier, New York.

Uотı, J. \& Y ҮıмĀKı, A. 1974. The occurence of Fusarium species in cereal grain in Finland. Ann. Agric. Fenn. 13: 5-17.

YLIMÄKı, A. 1970. The microflora of cereal seeds in Finland. Ann. Agric. Fenn. 9: 293-295.

Ylimä́, A., Koponen, H., HintikKa, E-L., Nummi, M., Niku-Paavola, M-L., Ilus, T. \& Enari, T-M. 1979. Mycoflora and occurrence of Fusarium toxins in Finnish grain. Techn. Res. Centr. Finl. Publ. 21.

Ms received Juli 11, 1985 


\section{Fusarium-sienten toksiinit ongelmana suomalaisessa rehussa ja viljassa}

\author{
Eeva Karppanen, Aldo Rizzo, Seija Berg, \\ Erja Lindfors ja Riitta Aho \\ Valtion eläinlääketieteellinen laitos, \\ PL 368, 00101 Helsinki
}

Hometoksiinien aiheuttamat haitat kotieläimille ovat olleet ajoittaisia ja văhăisiä Suomessa. Vuoden 1982 keväällä esiintyi kuitenkin lukuisia myrkytystapauksia, joita epăiltiin hometoksiinien aiheuttamiksi. Myöhemmin samana vuonna ilmeni, ettă rehujen raaka-aineeksi maahan tuotu huonolaatuinen maissi oli syyllinen eläinten sairastumisiin ja kuolemantapauksiin. Parin vuoden ajan jatkuneissa lukuisissa tutkimuksissa ei myrkytysten aiheuttajaa onnistuttu selvittämäăn. Vasta syksyllă 1984 tunnistettiin eräăstă rehunäytteestă Fusarium-homeitten metaboliitteihin kuuluva trikotekeeni, fusarenon-X. Tutkimukset kohdistettiin trikotekeeneihin ja syksyn kuluessa voitiin useista rehunäytteistă tunnistaa myös nivalenoli ja deoksinivalenoli eli vomitoksiini.

Vuoden 1984 kesă ja syksy olivat hyvin sateisia ja ilman kosteus oli usein suuri. Olosuhteet olivat suotuisia homeiden kasvulle, mikä aiheutti myrkytystapausten jyrkän lisaaăntymisen useilla eri eläinlajeilla. Kun kaikki sairastuneet tai kuolleet eläimet olivat saaneet yksinomaan tehdasvalmisteista rehua, niin epäilykset rehutehtaiden saastumisesta Fusarium-homeilla vahvistuivat. Suoritetuissa selvityksissä kävi ilmi, että rehutehtaiden siiloissa ja tuotantolinjoilla oli kondensoituneen veden kostuttamissa paikoissa Fusarium-pesăkkeită. Erăăn tehtaan tuotantolinjalta, eristettiin ja tunnistettiin kaksi Fusarium-lajia, $F$. graminearum ja $F$. poae. Myöhemmin varmistuivat epäilyt siitä, ettă trikotekeenejă esiintyi myös sateisilta pelloilta korjatussa kotimaisessa viljassa.

Trikotekeenit ovat voimakkaasti solu- ja dermotoksisia, joten niiden toteamiseksi voidaan käyttăă useita biologisia menetelmiä. Omissa tutkimuksissamme olemme käyttäneet soluviljelmiå, suolaisen veden äyriăistoukkaa (Artemia salina) ja kanin ihotestiä erikoisesti näytteiden esitutkinnassa. Tuloksissa on esitetty puhtailla malliaineilla suoritettujen kokeiden tulokset 6 trikotekeenin pienimmistä pitoisuuksista, jotka voidaan todeta soluviljelmissă ja tunnettujen maaărien vaikutus kanin ihotestissă. Menetelmien käytön soveltuvuuteen ja luotettavuuteen on kiinnitetty huomiota. Kuuden trikotekeenin (deoksinivalenoli, nivalenoli, fusarenon-X, diasetoksiskirpenoli, T-2-toksiini ja HT-2-toksiini) tunnistamiseksi ja kvantitatiiviseksi mäărittämiseksi on kehitetty kemiallinen me- netelmä. Menetelmässă on painotettu toksiinien eristämistă ja puhdistamista tehdasvalmisteisesta rehusta, joka osoittautui hyvin vaikeaksi tutkimusmateriaaliksi. Myös menetelmässä käytettävien tarvikkeiden ja reagenssien puhtaus oli huomioitava häiritsevien yhdisteiden vähentämiseksi. Trikotekeenit on analysoitu silyylijohdannaisina kapillaarikaasukromatograafisesti EC-detektoria käyttäen ja tunnistaminen on varmistettu massaspektrometrisesti. Menetelmăn herkkyys deoksinivalenolille, nivalenolille ja fusarenon-X:lle on $1 \mathrm{ug} / \mathrm{kg}$ ja diasetoksiskirpenolille, HT-2- ja T-2-toksiineille $7-20 \mathrm{ug} / \mathrm{kg}$ rehua tai viljaa.

Eri eläinlajien rehuista saaduista analyysituloksista on esitetty esimerkkejä rinnan eläimillä esiintyneiden oireiden kanssa. Tuloksia ja niiden merkitystă arvioitaessa on huomioitava seuraavat asiat:

Hometoksiinit ovat aina epảtasaisesti jakautuneina năytemateriaalissa ja edustavan năytteen saaminen suurista rehueristă on vaikeaa.

Tulosten vertaaminen kirjallisuudessa esitettyihin arvioihin ei ole mahdollista, koska kirjallisuudessa esiintyvăt tiedot koskevat tavallisesti vain yhden toksiinin myrkyllisyyttä. Useiden toksiinien yhteisvaikutus on tuntematon.

Näytteet on analysoitu 3-6 kuukautta myöhemmin kuin eläimillă sattuneet myrkytystapaukset ja analyyseissă todetut pitoisuudet eivăt ehkă vastaa myrkytyksen aiheuttanutta tasoa.

Kun maaliskuussa 1985 otettiin uudelleen esille $+4^{\circ}$ :ssa săilytettyjä näytteită, jotka edellisenă syksynă olivat olleet hyvin myrkyllisiă niin eläimille kuin biologisin kokein tutkittuina, ne osoittautuivat kanin iholla täysin myrkyttömiksi. Kemiallisella analyysillă saatiin tulokseksi jäämătasoa oleva maaărä deoksinivalenolia. Asiaa edelleen selvitettăessă kăvi ilmi, ettă vielă tămăn vuoden helmikuussa tavallisina rehuissa esiintyneet T-2- ja HT-2-toksiinit olivat hăvinneet huhtikuuhun mennessä. Diasetoksiskirpenolia oli muutamissa rehunăytteissă, mutta useimmat năytteet sisălsivăt vain văhăisiă jäămiă deoksinivalenolia. Erittäin kestävină pidetyt trikotekeenit olivat ajan mittaan hajonneet ja menettăneet biologisen tehonsa. Syyt tăhăn ilmiőoon ovat toistaiseksi tuntemattomia. 